\title{
Social Responsibility and Academic Achievement: A Perceptual Learning
}

\author{
Navita Nathani, Garima Mathur, Gunjan Dwivedi
}

\begin{abstract}
The rise of social responsibility in students has been exposed to be linked with academic achievement, success and higher self-esteem. Academic achievement stands for performance of a person to accomplished specific objectives in the instructional atmosphere of school, college and university. This study is an attempt to identify the domain that contributes to the development of social responsibility and competence in students which ultimately facilitates academic achievement. For this purpose the data gathered through a standardized questionnaire from the students of postgraduate and undergraduate courses like $M B A, B B A$ and engineering etc. The collected responses then analyzed through Exploratory Factor analysis, confirmatory factor analysis and other statistical tools. The results suggested that student's social responsibility contributes a lot in academic performance. However it is an important instrument in acquiring academic objectives. The study further reduced the items in four factors of social responsibility and four factors of academic achievement.
\end{abstract}

Keywords: Social Responsibility, Academic Achievement, CFA, Academic Performance.

\section{INTRODUCTION}

\section{A. CONCEPTUAL FRAMEWORK}

Academic background plays significant role in every person's life to act his/her responsibilities towards society. But nowadays the changed behaviour of youth is an issue of high concern for the parents and teachers. The stats proved that in India, maximum dropouts are taken place before higher studies. The reason behind this dropout may be the lack of sense of responsibility towards their academic achievements. In comparison to last two or three decades the manner and actions of students transform drastically. This kind of transformation also affects the social outlook of young generation. Being an integral part of society, every person is liable towards the social responsibility and the seed of behaving responsibly is propagated in the family and classroom. Family and classroom are the two most important places from where everyone learns the basic principles of life. The core concept arises from the thought of Aristotle that "Educating the mind without educating the heart is not education at all". The aim of our work was to broaden the current knowledge about social responsibility and academic performance of the students and also to validate measures for evaluating social responsibility and academic achievement, to demonstrate factors and analyze the relationship between these two variables.

Revised Manuscript Received on November 08, 2019.

* Correspondence Author

Dr. Navita Nathani, Professor Management, Prestige Institute of Management Gwalior, India.

Dr. Garima Mathur, Associate Professor, Prestige Institute of Management Gwalior, India.

Gunjan Dwivedi, Assistant Professor Finance, Prestige Institute of Management Gwalior, India.

\section{Social Responsibility}

Instruction and an understudy's social duty may change depending on the area, culture, zone of study and kind of college environment. Understudies ought to think about a few components while connecting with individuals outside the classrooms. Social obligation can likewise be viewed as considering appropriate direct and conduct around cohorts to guarantee they have a wonderful learning condition.

Understudy's social duty is the obligation of each student for his/her activities. It is ethically authoritative and recommends that every individual demonstrates so that limits the unfriendly effect to those quickly around them. It is a dedication everybody ought to have towards society in contributing towards social, social and natural causes.

\section{Academic Achievement}

Scholastic accomplishment as execution is the result of instruction for example the degree to which an understudy, instructor or foundation has accomplished their instructive objectives. Scholastic accomplishment is commonly estimated by examination or nonstop appraisal of the understudy however there is no broad concurrence on how he/she best tried or which perspectives are most significant, for example, aptitudes or information. It has been seen that understudies with higher mental capacity will in general accomplish exceptionally in scholastic settings.

\section{REVIEW OF LITERATURE}

There is a considerable literature available on these variables but what we know is largely based on study of school going children. Surprisingly very few studies found on college going students of professional courses. Scholastic achievement plays a very important role in student's life.

Reason (2013), explored that the concept of Personal and Social Responsibility was introduced by Knefelkemp and Hersh which was later redefined by Dey and Associates. Brodeur, (2013) stated that social responsibility is an ethical ideology that recommends that an individual or an organization has an obligation to act to benefit society at large.

Ozen Y (2012) found that student's social responsibility is not only a valued result but it is influential in acquiring knowledge and advancement of cognitive abilities. The impression of school is potentially high on children's minds. Social responsibility is important for students and pupils. Schools changed the pupil's self concept goals, beliefs about success etc. They exert strong influence on the subsequent education \& employment (Sylva k.1993). In other studies it was found that at the age of five, the children autonomy support and parents dimensions where

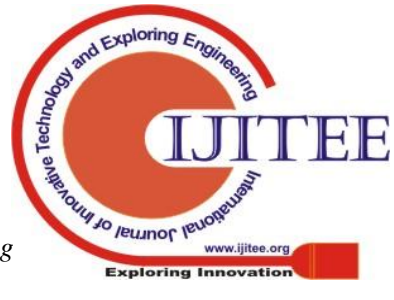


measured in various subjects. Many factors such as family environment, School environment, etc. contribute a lot in the overall development of social competency of children. The development process is versatile and linked through fine tuning of children with respective communities for scholastic achievement (Joussemet M., Koestner R., Lekes N., Landry R. 2005, Mulder S. 2008). However the study of Elias Maliki A E, Asain E S \& Kebbi J T (2010) suggested that the various dimensions of social responsibility are significantly related to academic achievement. It reveals that parental support on scholastic achievement is significant in case of girl child as they are more associated with their parents for academic information while in case of boys, it is the practical one.

Adetoro N. (2010) established that information use is an essential part of our daily lives which looks into social competence as correlated information use among library and information science. The study recommends the boosting of social competency skills of children through seminars and speeches. Some other researchers stated that blend of scholastic learning and emotional skills is the true standard for effective education for the world and the blend of academic learning and social emotional learning is the most promising way to achieving social responsibilities and for adopting a lifestyle. (M J 1997, Schonert K.A- Hymel R, S 2003)

Durlak J A, Weissberg R P, Dymnicki A P and Taylor R D \& Schellinger K B (2011) found that teaching and learning skills have strong social, emotional \& academic components. They learn in group effort with the teachers, peers and their families. Emotion can assist children's academic engagement, work ethics commitment and ultimate school accomplishment.

Fornells A. R \& Olivares, A. M. (1999), Botvin G J (2007) found that social problem solving abilities significantly foresees academic performance in college students after evaluating for their academic aptitude. Besides they found that the dimensions accountable for the relationship impulsive/casual problem solving and improving the social environment of students can augment school bonding which in turn may boost academic achievement and reduce behaviour problem. Involving students in planning and recognizing steps be meet their objectives.

National Library of Canada (2001) stated in a study that socially responsibly individuals demonstrate community, mindedness in their response to schools, local, national \& global issues \& events. This is the basis of execution \& flourishing democratic society. Social responsibility is often the main focus of activities but frequently it is secondary focal point of school activities.

\section{OBJECTIVES OF THE STUDY.}

1. To recognize the fundamental factors of social responsibility and academic achievement through EFA (Exploratory Factor Analysis) and CFA (Confirmatory Factor Analysis).

2. To establish the relationship between social responsibility and academic achievement.

\section{RESEARCH METHODOLOGY}

The study follows the quantitative approach and causal in nature. The population included professional students from various colleges of Gwalior region. The study was based on a study of Kathryn R. Wentzel (1991), where he did research on school going adolescents, while in our study the survey of college going students has been considered for taking the responses. The questionnaire for the study was adopted from the scale of Kathryn R. Wentzel (1991). Total numbers of 125 questionnaires were distributed among the target respondents, out of which 109 questionnaires were received. Non probability purposive sampling technique was used to select the sample as the purpose was to assess the responsibility and academic performance among the young students. The Software SPSS 18 was used to analyze the data for checking the Reliability of the statements, for recognizing factors of social responsibility and academic achievements. Statistical significance of reliability and data reduction of both the variables (social responsibility and academic achievement) analyzed through Cronbach's Alpha coefficients and EFA respectively. Further data was analysed using AMOS software to confirm the identified factors.

Reliability of both the constructs in the study (social responsibility and academic achievement) was established through computation of Cronbach's Alpha reliability coefficient for each construct separately. It was considered that reliability value more than .7 is highly reliable. Factor analysis was applied to find out the factors of Social responsibility and Academic Achievement. Regression was applied to know the cause and effect relationship between these variables.

\section{RESULTS \& DISCUSSION}

\section{Reliability Test}

\begin{tabular}{|c|c|c|}
\hline $\begin{array}{c}\text { Name of } \\
\text { Variables }\end{array}$ & $\begin{array}{c}\text { Cronbach's } \\
\text { Alpha }\end{array}$ & No. of Items \\
\hline $\begin{array}{c}\text { Social } \\
\text { Responsibility }\end{array}$ & .853 & 16 \\
\hline $\begin{array}{c}\text { Academic } \\
\text { Achievement }\end{array}$ & .861 & 17 \\
\hline
\end{tabular}

In case of the Reliability Analysis of Social Responsibility, where number of items was 16, we got Cronbach's alpha value as 0.853 and in case of Academic Achievement, where number of items was 17 , we got Cronbach's alpha value as 0.861 .

\section{Factor Analysis}

Principle Component Analysis was used to recognize factor by using grouping method and Kaiser as normalization method.

Kaiser - Meyer - Olkin Measures of Sampling Adequacy and Bartlett's Test of Sphericity: 
The results are shown in the table-

\begin{tabular}{|c|l|c|c|c|}
\hline $\begin{array}{l}\text { S. } \\
\text { No }\end{array}$ & $\begin{array}{l}\text { Variable } \\
\text { Name }\end{array}$ & $\begin{array}{l}\text { KMO } \\
\text { Value }\end{array}$ & $\begin{array}{c}\text { Bartlet's Test of } \\
\text { Sphericity } \\
\text { (Chi Square } \\
\text { Value) }\end{array}$ & $\begin{array}{l}\text { Significance } \\
\text { Level }\end{array}$ \\
\hline 1 & $\begin{array}{l}\text { Social } \\
\text { Responsibilit } \\
\mathrm{y}\end{array}$ & .830 & 932.019 & .000 \\
\hline 2 & $\begin{array}{l}\text { Academic } \\
\text { Achievement }\end{array}$ & .847 & 1077.287 & .000 \\
\hline
\end{tabular}

KMO was applied to check whether the data is sufficient or not for applying factor analysis. If the value of KMO comes in between .5 to 1 that means the data is normally distributed. It is obvious from the table given above that both the variables have KMO value greater than .5 and hence it is advisable to do further analysis. To check the sphericity of data the Bartlett test was applied, the Ho: Item to item correlation matrix was identity matrix resulted into clear rejection as the value of Chi-square in both the cases are significant at $0 \%$ level of significance.

The factors are calculated with the help of total variance explained and three factors were identified by the software in the first variable Social responsibility.

\section{Description of Factors of Social responsibility:}

Student Accountability is establishing policies and holding students accountable for complying with them to help them understand how their choices can affect the surrounding environment. Student Integrity depends on effectiveness of the academic honor code relies on participation of both the faculty and students. Student Conscientious is the sincere feeling to do the duty carefully and properly. For the teacher it is concerned to takes their profession seriously while for student it is concerned with sincere and deep interest in knowledge and hence students' reliability is the last factor emerged on account of social responsibility.

The factors are calculated with the help of total variance explain. Finally 4 factors emerged and calculated from the rotated component matrixes which are the outcome of SPSS software for the second variable.

\section{Description of Factors of Academic achievement:}

Student Appraisal is the responses and the credentials of the student performance can be evaluated by giving assignments, tasks and targets by teachers and seniors. The performance may be positive or negative depending upon their hard work to fulfill educational goals. Student Enhancement helps in improving the learning experience of students in higher education. The effort is to make the quality of teaching and the student learning even better. Student Superiority is the feeling of assuming oneself superior than others. Such unrealistic assumptions damage student's relationship with others in the classroom.

\section{Confirmatory Factor analysis}

After applying EFA the factors were confirmed through Confirmatory factor analysis by using AMOS for both the variables. Variable one identified 4 factors as student accountability (5 items), student integrity (4 items) and student conscientious (2 items) student learning ( 2 items).
The Goodness fit was checked through CFA in which few items were dropped to ascertain the important factors. First model of social responsibility is given below which was initial model:

\section{Initial Model of Social Responsibility}

In initial model the value of Chi Square was 72.356 which is significant at 0.005 significance level. It can be predicted that the model has good fit but on the other hand looking at the $\mathrm{Cmin} / \mathrm{df}$ value which was greater than 2 as the value is 2.420 in case of default model. Computing Cmin by df is an attempt to make model less dependent on sample size. However few researchers stated that the value should lie between 2-5, other researchers believed that the relative value should be $2: 1$ or lesser than 2 would reveal good fit (Carmines \& Mclver, 1981; Ullman, 2001). The other statistics Like GFI (.906), AGFI(.855) and RMR (.56) comes within range but other goodness of fit statistics like NFI, RFI, IFI,TLI and CFI are not above .9 except IFI and CFI demonstrating not perfect good fit of the model (Forza \& Filippini, 1998). It can be said that model have some internal problems because most of the indices are not able to meet to the cut off range of acceptance. Hence the model was revised to get perfect good fit.

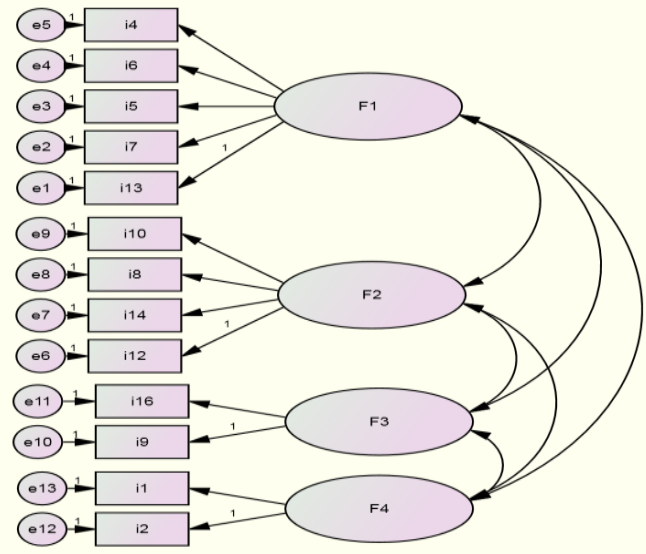

\section{Revised Model of Social Responsibility}

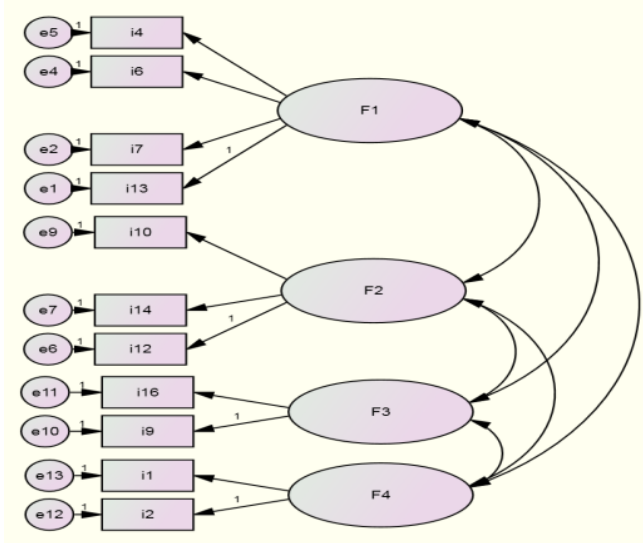


Table 1: Goodness of Fit Indices Comparison for Social Responsibility

\begin{tabular}{|l|c|c|}
\hline \multicolumn{2}{|c|}{ Goodness of Fit Indices Comparison } \\
\hline GOF Indices & Initial Model & Revised Model \\
\hline CMIN & 98.25 & 72.35 \\
\hline DF & 40 & 38 \\
\hline p-value & 0.005 & 0.001 \\
\hline CMIN/DF & 2.42 & 1.9 \\
\hline GFI & 0.906 & 0.938 \\
\hline AGFI & 0.855 & 0.893 \\
\hline CFI & 0.85 & 0.921 \\
\hline TLI & 0.658 & 0.886 \\
\hline NFI & 0.789 & 0.852 \\
\hline PNFI & 0.51 & 0.54 \\
\hline RMSEA & 0.061 & 0.067 \\
\hline Hoelter & $109 @ 5 \%$ & $147 @ 5 \%$ \\
& $122 @ 1 \%$ & $169 @ 1 \%$ \\
\hline
\end{tabular}

The measurement model was extended from initial model to revised model for making it more operational through CFA which can provide quantitative measures by examining goodness of fit. As per the statistics of goodness of fit the revised model can be best describe for predicting model's strength. The present model reduced first factor from 5 to 4 items and in second factors the items were reduced from four to three. The CMIN/DF value is 1.904 which is ranging in between 1-2 indicates a good fit. The goodness of fit indices like GFI (.938), AGFI (.893), NFI (.852), CFI (.921), TLI (.886) were close to .9 and passed cut off. There are certain other values to be considered to avoid unsighted acceptance. Further the good model fit was checked through RMSEA, if it is lesser than or equal to .05 then it is a good fit and if it is less than .08 then it is an adequate fit (Schumacker \& Lomax, 2004). However Hu \& Bentler (1999) suggested that RMSEA value should be less than or equal to 0.06 is the cutoff for a good model fit. PNFI is in range and Hoelter Index Test indicates the maximum sample size and the sample size limit is 147 @ 5\% significance level and 169 @1\% significance level which is acceptable for model fit.

\section{Academic Achievement}

The second variable was Academic achievements, after applying EFA we identified 5 factors as student appraisal (7 items), student performance (4 items) and student behaviour (3 items) student enhancement (1 item) and student superiority ( 1 item). To confirm the factors the goodness of fit of model was tested through CFA. The first model of academic achievement was initial model which is given below;

\section{Initial Model}

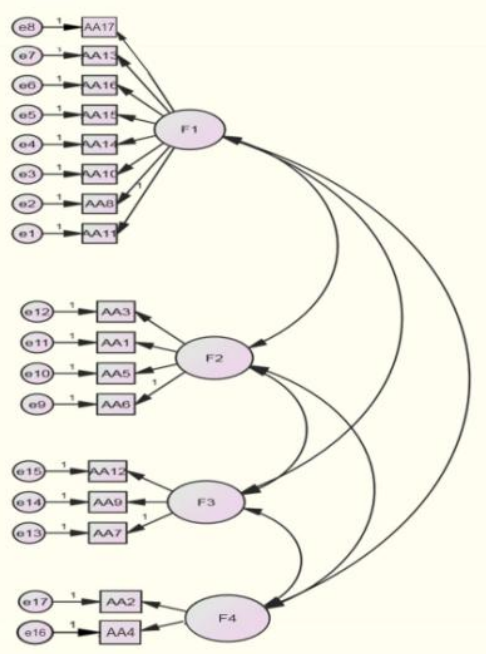

In initial model the value of Chi Square was 253.434 which is significant at 0.000 significance level. It can be predicted that the model has good fit but on the other hand looking at the $\mathrm{Cmin} / \mathrm{df}$ value which was greater than 2 as the value is 2.24 in case of default model. Computing Cmin by df is an attempt to make model less dependent on sample size. The other statistics Like GFI (.877), AGFI (.834) and RMR (.060) comes within range but other goodness of fit statistics like NFI, RFI, IFI,TLI and CFI are not above .9 except IFI and CFI showing not perfect good fit of the model (Forza and Filippini, 1998).The model has reduced to four factors as the last two statements included in a single factor and one item from first factor was ignored. It is obvious that the revised model has to be followed.

Table 2: Goodness of Fit Indices Comparison for Academic Achievement

\begin{tabular}{|l|c|c|}
\hline \multicolumn{3}{|c|}{ Goodness of Fit Indices Comparison } \\
\hline \multicolumn{1}{|c|}{ GOF Indices } & Initial Model & Revised Model \\
\hline CMIN & 253.434 & 146.203 \\
\hline DF & 113 & 71 \\
\hline p-value & 0 & 0 \\
\hline CMIN/DF & 2.243 & 2.04 \\
\hline GFI & 0.877 & 0.912 \\
\hline AGFI & 0.834 & 0.871 \\
\hline CFI & 0.721 & 0.893 \\
\hline TLI & 0.605 & 0.863 \\
\hline NFI & 0.747 & 0.816 \\
\hline PNFI & 0.53 & 0.55 \\
\hline RMSEA & 0.079 & 0.063 \\
\hline Hoelter & $109 @ 5 \%$ & $125 @ 5 \%$ \\
$119 @ 1 \%$ & $139 @ 1 \%$ \\
\hline
\end{tabular}

The measurement model was extended from initial model to revised model for making it more operational through CFA which can provide quantitative measures by examining goodness of fit. The model again dropped few items of first variables from eight to five and other remained same. As per the statistics of goodness of fit the revised model can be best describe for predicting model's strength. The CMIN/DF value is 2.04 which is ranging in between 1-2 indicates a good fit. The goodness of fit indices like 
GFI (.912), AGFI (.871), NFI (.816), CFI (.893), TLI (.863) were close to .9 and passed cut off. There are certain other values to be considered to be a good fit. Then the good model fit was checked through RMSEA, if it is lesser than or equal to .05 then it is a good fit and if it is less than .08 then it is an adequate fit (Schumacker \& Lomax, 2004). PNFI is in range and Hoelter test is also known as Hoelter Index for judging the adequate sample size. Conventionally Hoelter's $\mathrm{N}$ is greater than 200 is satisfactory. In the present study, it is acceptable as it comes in between 109-139. Hoelter Index Test indicates the maximum sample size and the sample size limit is 125 @ 5\% significance level and 139@ 1\% significance level which is acceptable for model fit.

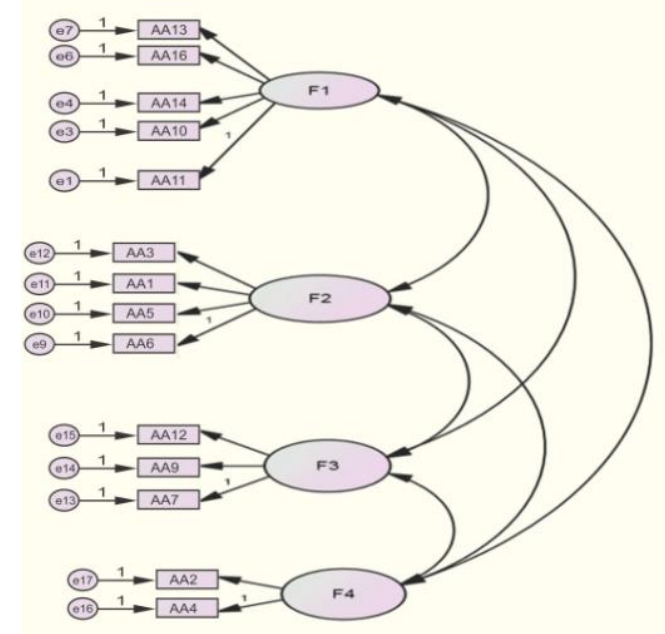

\section{Relationship between social responsibility and academic achievement}

Before applying regression Kolmogorov - Smirnov test was applied and found that the data was normal and hence we can proceed for regression.

\section{H1: Social responsibility positively affects academic achievement.}

ANOVA Summary indicated that the value of $F$ (116.878) was significant at) \% significance level, which means both the variables have strong relationship further model has a good fit. The R square value was .371 also explain that independent variable explain the dependent variable by $37.1 \%$. The t states (10.811) was also significant at $0 \%$ and beta value was .609 also explains that both the variables are positively correlated. The Academic achievement is dependent on social responsibility means the students who are responsible may get good scores. The model predicted that some other factors are also important for scholastic achievements but only social responsibility contributed $37 \%$ in academic achievement concludes that social responsibility seems to be an important variable for scholastic achievements. Self control plays an important role in mental soundness and thereby

\section{CONCLUSION}

The study concluded four factors of social responsibility as student accountability, student integrity, student Conscientious and students' reliability while in case of academic achievement the study concluded four factors as student's appraisal, performance, behavior, and last two factors clubbed as student's enhancement and superiority. There are certain factors which are positively affected the academic achievement while superiority is a negative factor which may affect the outcomes in adverse manner. The study further proved that self regulation is responsible for getting high achievement and good grades as there is a strong relationship between these variables. Social responsibility is an instrument in acquiring knowledge but it also depends on integrity between teachers and student. Teachers being role model exert powerful influence on imparting knowledge and education (Sylva k.1993) while students themselves responsible for being accountable and conscientious i.e. is the sincere feeling to do the duty carefully and properly.

\section{REFERENCES}

1. Berman, S. (1997). Social Consciousness and the Development of Social Responsibility. Albany, NY: State University of New York Press.

2. Blatz, W. E. (1944).Understanding the Young Child. New York: Wm Morrow \& Co. Blumenfeld, P. C Pintrich, P. R., \& Hamilton, V. L. (1986). Children's concepts of ability, effort, and conduct. American Educational Research Journal, 23, 95-104

3. Caspi, A., Elder, G. H., \& Bern, D.J. (1987). Moving against the world: Life-course patterns of explosive children. Developmental Psychology, 23, 308-313.

4. Bierman, K.L Kalvin, C. B., \& Heinrichs, B. S. (2015). Early childhood precursors and adolescent sequalae of grade school peer rejection and victimization. Journal of Clinical Child \& Adolescent Psychology, 44 (3), 367-379.

5. Blandon, A. Y., Calkins, S. D., Grimm, K. J., Keane, S. P., \& O’Brien, M. (2010). Testing a developmental cascade model of emotional and social competence and early peer acceptance. Development and Psychopathology, 22, 737-748.

6. Hartup, W. W. (1992). Having friends, making friends and keeping friends: Relationships as educational contexts. ERIC Digest. Champaign, IL: ERIC Clearinghouse on Elementary and Early Childhood Education.

7. Hill, A. L., Degnan, K. A., Calkins, S. D., \& Keane, S. P. (2006) Profiles of externalizing behavior problems for boys and girls across preschool: The roles of emotion regulation and inattention. Developmental Psychology, 42, 913-928.

8. Katz, L. G., \& McClellan, D. E. (1997). Fostering children's social competence: the teacher's role. Washington, DC: National Association for the Education of Young Children.

9. Kathryn R. Wentzel (1991). Relations between Social Competence and Academic Achievement in Early Adolescence. Child Development, 62(5), 1066-1078

10. Ladd, G. W. (1999). Peer relationships and social competence during early and middle childhood. Annual review of psychology. doi: 10.1146/annurev.psych.50.1.333

11. Ladd, G. W. (2000). The fourth R: Relationships as risks and resources following children's transition to school. American Educational Research Association Division E Newsletter, 19(1), 7, 9-11.

12. Ladd, G. W., \& Profilet, S. M. (1996). The child behavior scale: A teacher-report measure of young children's aggressive, withdrawn, and pro-social behaviors. Developmental Psychology, 32, 1008-1024. doi: 10.1037/0012-1649.32.6.1008

13. McClellan, D. E., \& Kinsey, S. (1999) Children's social behavior in relation to participation in mixed-age or same-age classrooms. Early Childhood Research \& Practice, 1(1)

14. Parker, J. G., \& Asher, S. R. (1987). Peer relations and later personal adjustment: Are low-accepted children at risk? Psychological Bulletin, 102,357-389.doi: 10.1037/0033-2909.102.3.357

15. Abbott, H. C. (1960) A study of the relationship between child-rearing practices and school achievement. Harvard Graduate School of Education.

16. Aiken, L. S., \& West, S. G. (1991). Multiple regression: Testing and interpreting interactions. Newbury Park, CA: Sage Publications.

17. Barber, B. K. (1996). Parental psychological control: Revisiting a neglected construct. Child Development, 67, 32963319 
18. Barber, B. K. (2002). Intrusive parenting: How psychological control affects children and adolescents. Washington, DC: American Psychological Association.

19. Cowen, E. L., Hightower, A. D., Pedro-Carroll, J. L., Work, W. C., Wyman, A., \& Haffey, W. G. (1996)

20. Darling, N., \& Steinberg, L. (1993). Parenting style as context: an integrative model. Psychological Bulletin, 113, 487496

21. Deci, E. L., Driver, R. E., Hotchkiss, L., Robbins, R. J., \& Wilson, I. M. (1993). The relations of mothers controlling vocalizations to children's intrinsic motivation. Journal of Experimental Child Psychology, 55, 151162

22. Deci, E.1,Eghrari, H., Patrick, B. C., \& Leone, D. R. (1994). Facilitating internalization: the self-determination theory perspective. Journal of Personality, 62, 118142

23. Deci, E. L., Koestner, R., \& Ryan, R. M. (1999). A meta-analytic review of experiments examining the effects of extrinsic rewards on intrinsic motivation Psychological Bulletin, 125, 627668

24. Deci, E. L., Nezlek,J., \& Sheinman, L.(1981).Characteristics of the rewarder and intrinsic motivation of the rewardee. Journal of Personality \& Social Psycho- logy, 40, 110

25. Deci, E. L., \& Ryan, R. M. (1985). Intrinsic motivation and self-determination in human behavior New York: Plenium Press.

26. Grolnick, W. S., Ryan, R.M. \& Deci, E.L. (1991). The inner resources for school achievement: Motivational mediators of children's perceptions of their parents. Journal of Educational Psychology, 83 (4), 508517

27. Harrington, D. M., Block, J. H., \& Block, J. (1987). Testing aspects of Carl Rogers theory of creative environments: Child-rearing antecedents of creative potential in young adolescents. Journal of Personality and Social Psychology, 52, 851856

28. Joussemet, M., Koestner, R., Lekes, N., \& Houlfort, N. (2004). Introducing un-interesting tasks to children: A comparison of the effects of rewards and autonomy support. Journal of Personality, 72 (1), 139166

29. Koestner, R., Ryan, R. M., Bernieri, F., \& Holt, K. (1984). Setting limits on children's behavior: The differential effects of controlling versus informational styles on intrinsic motivation and creativity. Journal of Personality, 52, 233248

30. Marchant, G. J., Paulson, S. E., \& Rothlis berg, B. A. (2001). Relations of middle school student's perceptions of family and school contexts with academic achievement. Psychology in the Schools, 38 (6), 505519

31. Ryan, R. M. (1995). Psychological needs and the facilitation of integrative processes. Journal of Personality, 63 (3), 397427

32. Ryan, R. M. \& Connell, J. P. (1989). Perceived locus of causality and internalization: Examining reasons for acting in two domains. Journal of Personality and Social Psychology, 57, 749761

33. Ryan, R.M., \& Grolnick, W. S. (1986). Origin sand pawns in the classroom: Self- report and projective assessments of individual differences in childrens perceptions. Journal of Personality and Social Psychology, 50, 550558

34. Sears, R. R., Maccoby, E. C., \& Levin, H. (1957). Patterns of child rearing. Evanston, IL: Row, Peterson. 